\title{
Bacterial Toxins Affect Early Events of T Lymphocyte Activation
}

Stanford J. Stewart, Veronica Prpic, James A. Johns, Frances S. Powers, Stanley E. Graber, James T. Forbes, and John H. Exton

Departments of Medicine, Pediatrics, and Molecular Physiology and Biophysics, and the Howard Hughes Medical Institute, Vanderbilt University School of Medicine, Nashville, Tennessee 37232; and the Veterans Administration Medical Center, Nashville, Tennessee 37212

\begin{abstract}
The effects of pertussis toxin and cholera toxin on early events of $T$ lymphocyte activation were examined in the $T$ lymphocyte cell line, Jurkat. Pertussis toxin treatment of these $\mathbf{T}$ cells increased inositol phosphates production and led to increases in intracellular free calcium concentration. These effects were produced by the isolated B (binding) subunit of pertussis toxin, alone. Inositol phosphates production resulting from perturbation of the $T$ cell antigen receptor-CD3 complex by MAb was not affected by pertussis toxin treatment but was markedly inhibited by cholera toxin. This effect of cholera toxin paralleled elevations in cAMP content. However, forskolin, in concentrations equipotent for cAMP production, was a weaker inhibitor of inositol phosphates production. Cholera toxin inhibition of inositol phosphates production did not result from inhibition of baseline incorporation of inositol into phosphoinositide substrates of phospholipase $C$. These studies underline the complexity of toxin effects on cellular systems and suggest that other approaches will be required to implicate guanine nucleotide-binding regulatory proteins in control of the early events of $T$ lymphocyte activation. However, the data presented here provide a molecular basis for the clinical observations of lymphocytosis and the in vitro observations of lymphocyte mitogenesis after pertussis toxin stimulation.
\end{abstract}

\section{Introduction}

The toxins of Vibrio cholerae (cholera toxin) and Bordetella pertussis (pertussis toxin) are typical A/B subunit toxins. Their B subunits confer binding specificity, whereas their A subunits possess ADP-ribosyltransferase activity (1). The pathogenetic actions of these toxins are thought to result primarily from their effects on a family of heterotrimeric regulatory proteins called guanine nucleotide-binding proteins ( $G$ proteins) (2). $G$ protein actions are best understood in the adenylate cyclase system. There, receptors for stimulatory and inhibitory hormones interact with stimulatory and inhibitory $G$ proteins $\left(G_{s}\right.$

Portions of this work were presented at the American Society of Hematology, San Francisco, CA, December 1986, and at the American Federation for Clinical Research, San Diego, CA, May 1987.

Address reprint requests to Dr. Stanford J. Stewart, F-322, Veterans Administration Medical Center, Nashville, TN 37212. 1988.

Received for publication 4 August 1987 and in revised form 9 June

J. Clin. Invest.

(c) The American Society for Clinical Investigation, Inc.

0021-9738/89/01/0234/09 \$2.00

Volume 83, January 1989, 234-242 and $\left.G_{i}\right),{ }^{1}$ respectively $(3-5)$. These interactions apparently lead to conformational changes in the $G$ proteins that increase the affinity of their alpha subunits for GTP and cause those subunits to dissociate from the beta-gamma subunits. Subsequently $G_{s}$ activates, whereas $G_{i}$ inhibits adenylate cyclase. Cholera toxin ADP-ribosylates the alpha chain of the $G_{s}$, thereby activating adenylate cyclase, whereas pertussis toxin ADP-ribosylates and inactivates $G_{i}$, thereby removing inhibitory hormonal influences on adenylate cyclase activity (6).

Recent evidence suggests that another second messenger generating system may be controlled by $G$ proteins. Inositol $1,4,5$ trisphosphate (Ins 1,4,5- $\mathrm{P}_{3}$ ) and diacylglycerol, which release intracellular stores of calcium (7) and activate protein kinase $C(8)$, respectively, are produced by the receptor-mediated, phosphodiesteratic cleavage of phosphatidylinositol bisphosphate $\left(\mathrm{PIP}_{2}\right)$ catalyzed by phospholipase $\mathrm{C}(9)$. Support for a role of $G$ proteins in control of phospholipase $C$ activity comes from reports that addition of the nonhydrolyzable analogue of GTP, GTP- $\gamma-S$, to preparations of membranes, leads to the accumulation of inositol trisphosphate and a concurrent decrement in phosphatidylinositol bisphosphate $(10,11)$ and from multiple studies from several laboratories describing the abolition, in pertussis toxin-treated neutrophils (11-17), of inositol phosphates generation and chemotaxis in response to the chemotactic peptide, FMLP. The G protein involved in these neutrophil responses recently has been characterized (18-20). This unique G protein is ADP-ribosylated by both pertussis and cholera toxins, and has an apparent molecular weight of 40,000 .

Physiologic $T$ lymphocyte activation begins when the $T$ cell receptor/CD3 complex encounters antigen in the context of products of the MHC (21). MAb directed against the T cell receptor for nominal antigen $\left(T_{i}\right)$ or the CD3 structure have been shown to mimic antigen (22) and lead to changes consistent with the activated state. Among these changes are rapid production of several inositol polyphosphates $(23,24)$, increases in intracellular calcium concentration $\left(\left[\mathrm{Ca}^{2+}\right]_{i}\right)(25$, 26 ), production of new mRNA for $\gamma$-IFN, IL2 (27), and IL2 receptor $(28)$, and proliferation $(29,30)$. Several of the early events of $T$ lymphocyte activation are dependent upon the phospholipase C-catalyzed cleavage of $\operatorname{PIP}_{2}(23)$ to the second messengers, Ins $1,4,5-\mathrm{P}_{3}$ and diacylglycerol.

Long-standing clinical observations of marked lymphocytosis during the paroxysmal phase of whooping cough (31) and several laboratory studies (32-34) suggest that pertussis toxin

1. Abbreviations used in this paper: cRPMI, RPMI 1640 medium supplemented with $15 \%$ fetal bovine serum and penicillin-streptomycin; DPBS, Dulbecco's phosphate-buffered saline; $G_{i}$, inhibitory guanine nucleotide-binding protein; $G_{s}$, stimulatory guanine nucleotidebinding protein; Ins $1,4,5-\mathrm{P}_{3}$, inositol $1,4,5$ trisphosphate; PI, phosphatidylinositol; PIP, phosphatidylinositol phosphate; PIP $_{2}$, phosphatidylinositol bisphosphate. 
is a T lymphocyte activator. Recently, Imboden et al. (35) have suggested that cholera toxin inhibits $\mathrm{T}$ cell receptor-mediated increases in inositol phosphates production and $\left[\mathrm{Ca}^{2+}\right]_{\mathrm{i}}$. Therefore, a reevaluation of the role of bacterial toxins in $\mathrm{T}$ lymphocyte activation was warranted. This report presents studies investigating the effects of bacterial toxins on the T cell antigen receptor-CD3 complex-mediated, phospholipase Cdependent generation of inositol phosphates and subsequent increases in $\left[\mathrm{Ca}^{2+}\right]_{i}$ in a $\mathrm{T}$ lymphocyte cell line system. We demonstrate that bacterial toxins affect basal and $T$ cell antigen receptor/CD3-mediated production of inositol polyphosphates and $\left[\mathrm{Ca}^{2+}\right]_{i}$. However, in large measure these effects appear to be independent of ADP-ribosylation of putative phospholipase $\mathrm{C}$-associated guanine nucleotide-binding regulatory proteins.

\section{Methods}

Cell lines, MAb, and toxins. The human T lymphocyte cell line, Jurkat (36), was used in this study. The cell line was maintained in RPMI 1640 medium (Gibco Laboratories, Grand Island, NY) supplemented with $15 \%$ fetal bovine serum (Gibco Laboratories) and penicillinstreptomycin (Gibco Laboratories) (cRPMI). The anti-CD3(T3) MAb anti-Leu-4 $(37,38)$, was obtained from Becton-Dickinson \& Co., Mountain View, CA. Pertussis toxin was obtained from List Biological Laboratories, Campbell, CA. Cholera toxin was from CalbiochemBehring Corp., La Jolla, CA.

Isolation of pertussis toxin B subunit. Pertussis toxin B subunit was prepared by the method of Burns et al. (39). In brief, whole pertussis toxin was dissolved in buffer $\mathrm{A}(0.01 \mathrm{M}$ Na phosphate buffer $\mathrm{pH} 7.0$ containing $3 \mathrm{M}$ urea, 1\% 3-[(3-cholamidopropyl)dimethylammonia]1-propane sulfonate (Calbiochem-Behring Corp.), and $100 \mu \mathrm{M}$ ATP). After incubation at $37^{\circ} \mathrm{C}$ for $15 \mathrm{~min}$, the dissociated chains were applied to a column of carboxymethyl Sepharose CL-6B (Pharmacia Fine Chemicals, Uppsala, Sweden) which had been equilibrated in buffer A. Unbound $A$ subunit of pertussis toxin was removed by washing the column with buffer $A$. Bound B subunit of pertussis toxin was eluted in $0.2 \mathrm{M} \mathrm{K}$ phosphate buffer, $\mathrm{pH} 7.5$, containing $2 \mathrm{M}$ urea. Aliquots of these fractions were analyzed by SDS-PAGE, silver staining, and densitometry. B subunit preparation was $>98 \%$ free of contaminating A subunit.

Cell labeling. Jurkat cells were suspended in Eagle's basal medium lacking myo-inositol (Gibco Laboratories) containing 10\% dialyzed, heat-inactivated, fetal bovine serum. To the cell suspension, $\left[{ }^{3} \mathrm{H}\right] m y o-$ inositol ( $15 \mathrm{Ci} / \mathrm{mmol}$ ) (American Radiolabeled Chemicals, St. Louis, MO) was added at $40 \mu \mathrm{Ci} / 2 \times 10^{7}$ cells $/ \mathrm{ml}$. Cells were incubated for $3 \mathrm{~h}$ at $37^{\circ} \mathrm{C}$ in a $5 \% \mathrm{CO}_{2}$ environment.

Toxin treatments. After labeling, cells were washed in Dulbecco's phosphate-buffered saline (DPBS), and placed in cRPMI, or, in certain experiments, plain RPMI lacking fetal bovine serum. Cholera toxin or pertussis toxin was added at various concentrations. In certain experiments, forskolin (Sigma Chemical Co., St. Louis, MO) was added to other cells suspensions as a control. Cells were incubated for a period of time, typically $1 \mathrm{~h}$, at $37^{\circ} \mathrm{C}, 5 \% \mathrm{CO}_{2}$, then washed and resuspended in a simplified medium of $145 \mathrm{mM} \mathrm{NaCl}, 5 \mathrm{mM} \mathrm{KCl}, 1 \mathrm{mM} \mathrm{Na}_{2} \mathrm{PO}_{4}, 1$ $\mathrm{mM} \mathrm{CaCl}_{2}, 0.5 \mathrm{mM} \mathrm{MgSO}_{4}, 5 \mathrm{mM}$ glucose, $10 \mathrm{mM}$ Hepes, $\mathrm{pH} 7.4$ for stimulation studies.

Stimulation studies. Cell suspensions were transferred to a $37^{\circ} \mathrm{C}$ $\mathrm{H}_{2} \mathrm{O}$ bath. After $10 \mathrm{~min}$, anti-Leu- $4 \mathrm{MAb}$ was added at a dilution of 1:100. At various times before and after stimulation, aliquots of cell suspensions were removed and added to $\mathrm{CCl}_{3} \mathrm{COOH}$ (final concentration $10 \%)$. Precipitated material was removed by centrifugation and supernatants were harvested. Aliquots of supernatants were set aside for cAMP determination. Remainders of the supernatants were washed five times with equal volumes of ethyl ether to remove the acid and then were frozen before analysis. In certain experiments, dibu-
tyryl-cAMP (Boehringer Mannheim Biochemicals, Indianapolis, IN) was added to the cell suspension before stimulation.

Analysis of inositol phosphates. Inositol phosphates, InsP through Ins $\mathrm{P}_{4}$, were isolated by anion-exchange chromatography on resin columns (AG1-X8) as previously described (24). Samples were eluted in a linear gradient from $\mathrm{H}_{2} \mathrm{O}$ to $0.1 \mathrm{M}$ formic acid/ammonium formate 2.0 M. Fractions were collected, scintillant was added, and radioactivity of the fractions was determined by liquid scintillation counting.

Analysis of phosphoinositides. Inositol-containing lipids were analyzed by the methods of Berridge (9). Material precipitated from control and toxin-treated cells in 10\% TCA was taken up in $3 \mathrm{ml}$ chloroform/methanol (1:2). To this mixture, $1 \mathrm{ml} 2.4 \mathrm{~N} \mathrm{HCl}, 1 \mathrm{ml}$ chloroform, and $1 \mathrm{ml} \mathrm{H}_{2} \mathrm{O}$ were added. After phase separation, the lower organic phase was collected. The upper phase was reextracted twice by addition of $2 \mathrm{ml}$ chloroform and the lower phases were combined. Finally, the combined lower phase was washed twice with $2 \mathrm{ml}$ of $1 \mathrm{~N}$ $\mathrm{HCl} /$ methanol (1:1), before being evaporated to dryness in an apparatus (Speed-Vac; Savant Instruments, Hicksville, NY). The dried lipid samples were deacylated by incubation with $0.75 \mathrm{ml}$ methylamine reagent containing monomethylamine/methanol/water/butanol (5:4:3:1) at $53^{\circ} \mathrm{C}$ for $30 \mathrm{~min}$. The methylamine reagent was evaporated in a stream of dry $\mathrm{N}_{2}$. The dried residue was taken up in $1 \mathrm{ml}$ of $\mathrm{H}_{2} \mathrm{O}$ and fatty acids removed by addition of $1.2 \mathrm{ml}$ of a mixture of $n$-butanol/hexane/ethyl formate (20:4:1). After being shaken, the upper organic phase was removed and the lower aqueous phase washed again with the same mixture. Finally, the lower phase was applied to $1.5-\mathrm{ml}$ columns of AG1-X8 (formate form) anion-exchange resin. After washing with $\mathrm{H}_{2} \mathrm{O}$, radioactivity arising from phosphatidylinositol (PI) was eluted in a buffer containing $5 \mathrm{mM} \mathrm{Na}$ borate, $0.18 \mathrm{M}$ formic acid, that arising from phosphatidylinositol phosphate (PIP) was eluted in a buffer containing $0.1 \mathrm{M}$ formic acid, $0.3 \mathrm{M}$ ammonium formate, and that arising from PIP $_{2}$ was eluted in a buffer containing $0.1 \mathrm{M}$ formic acid, $0.75 \mathrm{M}$ ammonium formate. All eluted fractions were analyzed for radioactivity by liquid scintillation counting.

Calcium studies. Jurkat cells were suspended in RPMI 1640 medium, lacking serum and antibiotics, buffered with $20 \mathrm{mM}$ Hepes. To this suspension, fura-2 acetoxymethyl ester (40) (Calbiochem-Behring Corp.) dissolved in 25\% Pluronic F-127 (BASF; Wyandotte, Wyandotte, MI) in DMSO was added at a concentration of $20 \mu \mathrm{g} / \mathrm{ml}$. Cells were incubated at $37^{\circ} \mathrm{C}$ for $45 \mathrm{~min}$. Cells were washed and resuspended in Hepes-buffered RPMI 1640 until study. For study, cells were suspended in a simplified medium of $145 \mathrm{mM} \mathrm{NaCl}, 5 \mathrm{mM} \mathrm{KCl}$, $1 \mathrm{mM} \mathrm{Na}_{2} \mathrm{HPO}_{4}, 1 \mathrm{mM} \mathrm{CaCl}_{2}, 0.5 \mathrm{mM} \mathrm{MgSO}_{4}, 5 \mathrm{mM}$ glucose, and $10 \mathrm{mM}$ Hepes, pH 7.4, as described by Tsien et al. (41). Single-cell observations were performed by placing cell suspensions in a temperature-controlled tissue bath on an inverted microscope stage. A single cell was chosen for study and centered over a $12.5-\mu \mathrm{m}$ aperture. The cell was then illuminated with ultraviolet light of 340 or $380 \mathrm{~nm}$ alternating 20 times per second using an illuminator system (Deltascan; Photon Technology International, Princeton, NJ). Fluorescence at $510 \mathrm{~nm}$ was detected with a photomultiplier tube and stored using a computer (IBM Instruments, Inc., Danbury, CT). Population experiments were performed by single wavelength $(340 \mathrm{~nm})$ illumination of a stirred cellular suspension in a spectrofluorometer (SF-330; Varian Associates, Inc., Palo Alto, CA), measuring fluorescence at $510 \mathrm{~nm}$.

Determination of CAMP content. Aliquots of cell samples in $10 \%$ TCA were extracted three times with water-saturated ethyl ether and then heated to $50^{\circ} \mathrm{C}$ for $25 \mathrm{~min}$ to remove the TCA and residual ether. Each sample was diluted in sodium acetate buffer, $\mathrm{pH}$ 4.0, (final concentration $50 \mathrm{mM}$ ), acetylated, and assayed for cAMP content by competition RIA using adenosine 3':5'-cyclic phosphoric acid 2'-Osuccinyl ${ }^{125}$ I-iodotyrosine methyl ester (New England Nuclear) as previously described (42). Radioactivity was determined by gamma counting.

Flow cytometric analysis. Toxin pretreated or control Jurkat cells $\left(1 \times 10^{6}\right)$ were incubated with $\sim 1 \mu \mathrm{g}$ of MAb directed against CD3 (anti-Leu-4, Becton-Dickinson \& Co.), CD2 (anti-Leu-5, Becton Dickinson \& Co.), transferrin receptor (Becton-Dickinson \& Co.), or 
CD8 (class-matched negative control, anti-Leu-2a, Becton-Dickinson \& Co.) for $20 \mathrm{~min}$ at $0^{\circ} \mathrm{C}$ in the presence of $\mathrm{NaN}_{3}$. Cells were washed and incubated with a fluorescein-conjugated sheep anti-mouse IgG polyclonal antiserum at $0^{\circ} \mathrm{C}$ for $20 \mathrm{~min}$. Cells again were washed and fixed in 1\% paraformaldehyde. Binding of the MAb to cells was analyzed by measuring fluorescence in a flow cytometer (Ortho $5 \mathrm{OH}$; Ortho Diagnostic System, Westwood, MA) using the linear amplifier.

Analysis of toxin substrates. Jurkat cells were pretreated for $1 \mathrm{~h}$ with either cholera toxin, pertussis toxin, or no toxin. Cells were washed and subjected to sonication. Membranes were prepared by differential centrifugation: after discarding a 3,640-g pellet, material precipitated at $34,770 \mathrm{~g}$ was resuspended in PBS. $10 \mathrm{mM} \mathrm{MgCl}_{2}$ was added to preparations to be treated with cholera toxin. Membrane preparations of control and toxin-treated cells were then incubated with ${ }^{32} \mathrm{P}-\mathrm{NAD}$ in the absence or presence of the relevant toxin, which had been activated by preincubation in 20 mM DTT (6). Membranes were harvested by centrifugation, dissolved in SDS-sample buffer, applied to $10 \%$ polyacrylamide gels, and subjected to electrophoresis (43). Resulting gels were analyzed by autoradiography.

\section{Results}

Pertussis toxin increases baseline inositol phosphates content in Jurkat cells. Jurkat cells were incubated with pertussis toxin for $1 \mathrm{~h}$. Fig. 1 demonstrates that this treatment significantly increased the contents of inositol bis- through tetrakis- phosphate, and total inositol phosphates in the treated cells. The failure of the difference in inositol monophosphate contents to reach statistical significance may have been because the free inositol peak trailed into the inositol monophosphate fraction in most chromatographic separations. When cAMP contents were analyzed in these pertussis toxin-treated Jurkat cells, a modest, statistically insignificant increase in cAMP content was seen (Fig. 1). These results raised the question: was pertussis toxin acting directly, or indirectly by inactivating some inhibitory influence on phospholipase $\mathrm{C}$ activity, thereby allowing stimuli of phospholipase $C$ (possibly present in the serum supplemented medium) to exert their influence? Pertussis toxin treatment was carried out under several serum conditions. Fig. 2 demonstrates that pertussis toxin increased inositol phosphates production in the presence of two lots of FCS and normal human serum. However, increased inositol phosphates production was most marked in the absence of serum. These results implied a direct stimulatory effect of the toxin on the Jurkat cells, not simply inactivation of inhibitory mechanisms allowing stimulatory effects of factors in the serum to become manifest. Furthermore, cold inositol contained in the serum supplement, had no significant effect on the labeling of phosphoinositide substrates for inositol phosphates production (data not shown). Finally, in serum-free

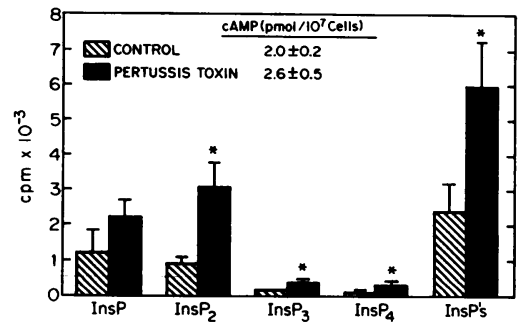

Figure 1. Pertussis toxin induces inositol phosphates production. Jurkat cells, labeled with $\left[{ }^{3} \mathrm{H}\right]$ myo-inositol were suspended in complete RPMI and incubated in the absence (striped bars) or presence (black bars) of $1 \mu \mathrm{g} / \mathrm{ml} \mathrm{per-}$

tussis toxin for $60 \mathrm{~min}$. Shown are means and $\mathrm{SE}$ of the means from four experiments. Statistical analysis was by one-way analysis of variance (ANOVA) and Fischer's least significant difference test. $*, P$ $<0.05$.

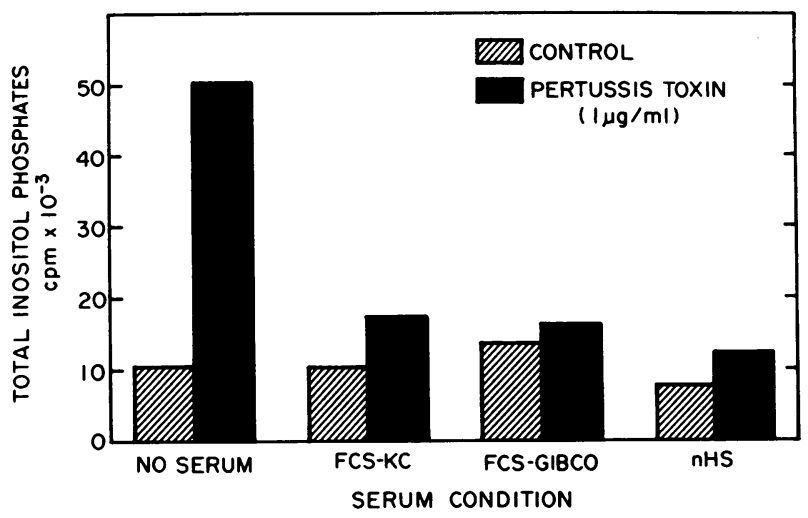

Figure 2. Pertussis toxin effects on inositol phosphate generation under various serum conditions. Jurkat cells labeled with $\left[{ }^{3} \mathbf{H}\right]$ myoinositol were resuspended in plain RPMI (no serum), RPMI containing 15\% FCS (FCS-KC and FCS-GIBCO), or RPMI containing $10 \%$ normal human serum (nHS) and incubated for $60 \mathrm{~min}$ with $1 \mu \mathrm{g} / \mathrm{ml}$ pertussis toxin.

conditions, no changes in cAMP content between pertussis toxin-treated and control cells were noted (data not shown).

The time course of inositol phosphates production in response to pertussis toxin was examined. Fig. 3 shows that total inositol phosphates production in pertussis toxin-treated cells peaked between 60 and $90 \mathrm{~min}$ of incubation. This time course of inositol phosphates formation was similar to that induced by the plant lectin Con A, a frequently used lymphocyte mitogen. However, the magnitude of inositol phosphates production was much smaller with pertussis toxin, under these conditions.

Pertussis toxin effects on Tlymphocytes are dependent on the $B$ subunit. The B subunit of pertussis toxin was examined for its ability to stimulate inositol phosphates production in the $T$ lymphocyte cell line. Fig. 4 demonstrates that the purified B subunit produced increases in inositol phosphates production comparable to those produced by holotoxin. B subunit responses were not attributable to contaminating holotoxin.

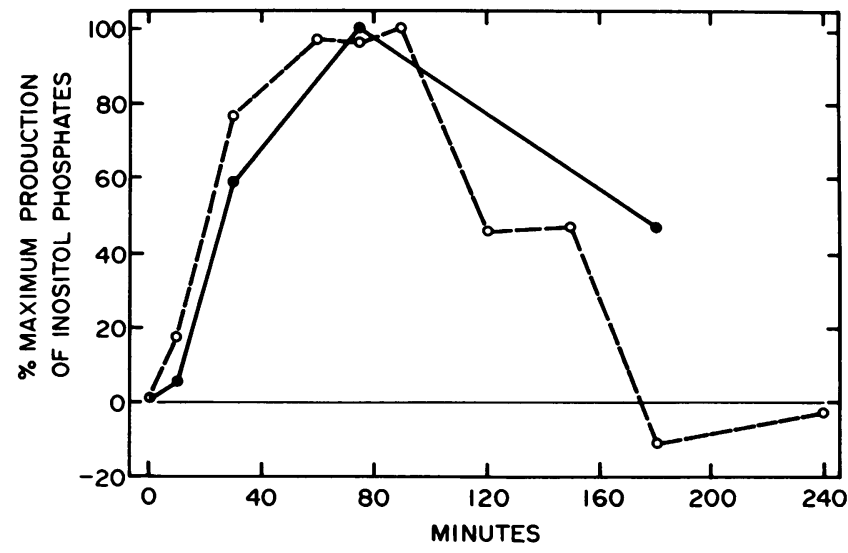

Figure 3. Time course of pertussis toxin-induced inositol phosphate production. Jurkat cells, labeled with $\left[{ }^{3} \mathrm{H}\right]$ myo-inositol, were stimulated by $1 \mu \mathrm{g} / \mathrm{ml}$ pertussis toxin (dotted line) or $20 \mu \mathrm{g} / \mathrm{ml} \mathrm{Con} \mathrm{(solid}$ line) for various times. $\circ$, pertussis toxin $(\max =4,525 \mathrm{cpm})$; $\bullet$, Con A $(\max =133,602 \mathrm{cpm})$. 

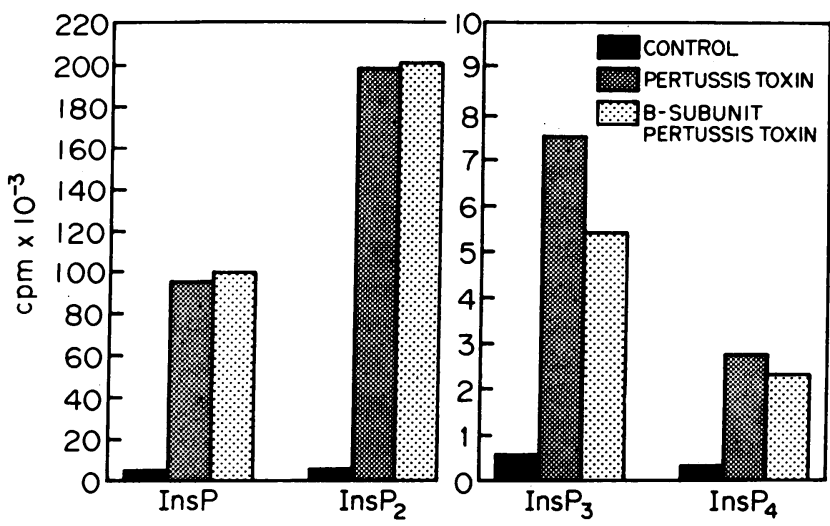

Figure 4. B subunit of pertussis toxin effects on inositol phosphates production. Jurkat cells labeled with $\left[{ }^{3} \mathrm{H}\right]$ myo-inositol were resuspended in RPMI 1640 without serum and incubated under control condition (black bars), or with $1 \mu \mathrm{g} / \mathrm{ml}$ pertussis toxin (stippled bars), or with an equimolar amount of B subunit of pertussis toxin (dotted bars) for $90 \mathrm{~min}$. Data shown are the average of observations from two separate experiments. No observation differed from the average by $>10 \%$.

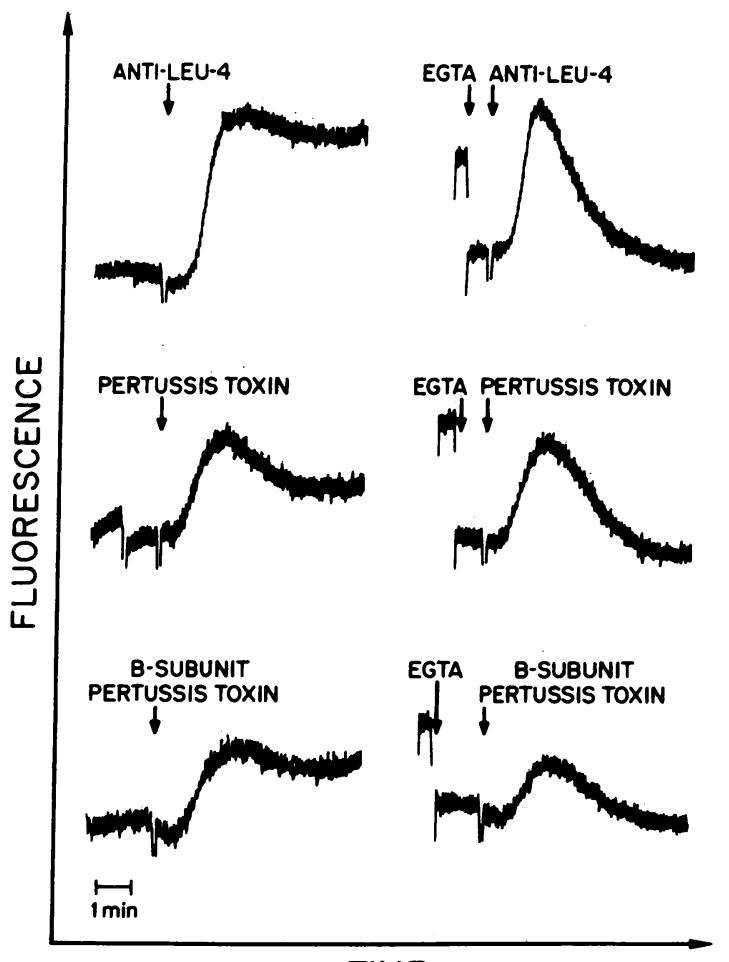

TIME

Figure 5. Effects of whole pertussis toxin and B subunit of pertussis toxin on intracellular calcium concentration in Jurkat cells. Jurkat cells, labeled with fura-2, were resuspended in simplified medium (1 $\mathrm{mM} \mathrm{Ca}{ }^{2+}$ ) in a stirred cuvette at $37^{\circ} \mathrm{C}$. Cells were stimulated in the absence (left-hand curves) or presence (right-hand curves) of $2 \mathrm{mM}$ EGTA with anti-Leu-4 (top curves), $1 \mu \mathrm{g} / \mathrm{ml}$ whole pertussis toxin (middle curves), or an equimolar amount of B subunit of pertussis toxin (lower curves). Displayed is the relative fluorescence of cells excited at $340 \mathrm{~nm}$ and measured at $500 \mathrm{~nm}$.
Dose-response data (not shown) of pertussis toxin-induced inositol phosphates production showed that a $2 \%$ contamination of purified B subunit with holotoxin could account for only $15 \%$ of the increase in production seen here. Similarly, treatment of Jurkat cells with B subunit of pertussis toxin led to changes in intracellular calcium concentration that were comparable to those produced by holotoxin. Fig. 5 compares changes in $\left[\mathrm{Ca}^{2+}\right]_{i}$ induced by the anti-CD3 MAb anti-Leu-4, with those produced by whole pertussis toxin and isolated $B$ subunit of pertussis toxin. Whereas holotoxin and B subunit produced smaller changes than did anti-Leu-4, the changes had certain similarities. They began rapidly, within minutes of addition of the stimulus, had a rapid upswing phase, and a more prolonged, somewhat lower plateau phase. As previously demonstrated for anti-CD3 stimulation (23), EGTA pretreatment of toxin-stimulated cells affected the initial phase of intracellular calcium increase very little, but abolished the later prolonged elevation phase (right column). These data suggest that pertussis toxininduced changes in $\left[\mathrm{Ca}^{2+}\right]_{\mathrm{i}}$ initially were dependent upon release of $\mathrm{Ca}^{2+}$ from intracellular stores, presumably through an Ins 1,4,5- $\mathrm{P}_{3}$-dependent mechanism.

At a single cell level, differences arose between anti-CD3 induced changes in $\left[\mathrm{Ca}^{2+}\right]_{\mathrm{i}}$ and those produced by pertussis toxin. Fig. 6 shows that the MAb produced rapid increases in $\left[\mathrm{Ca}^{2+}\right]_{i}$, falling to elevated plateau levels within $8 \mathrm{~min}$. In contrast, after a longer period of quiescence, whole pertussis toxin and the $B$ subunit of pertussis toxin caused a rapid repetitive spiking pattern of $\left[\mathrm{Ca}^{2+}\right]_{i}$. In no cell stimulated with the MAb was a second spike of increased $\left[\mathrm{Ca}^{2+}\right]_{i}$ observed. The time differences apparent in the single-cell experiments compared with the population experiments, probably relate to the fact that, in the single-cell system, we relied upon simple diffusion to disperse the stimuli, whereas in the population experiments, cells were maintained in a stirred cuvette.

Pertussis toxin fails to inhibit CD3-mediated inositol phosphates production. When pertussis toxin-treated Jurkat cells were subjected to stimulation with the anti-CD3 MAb, antiLeu-4, inositol phosphates production increased in much the

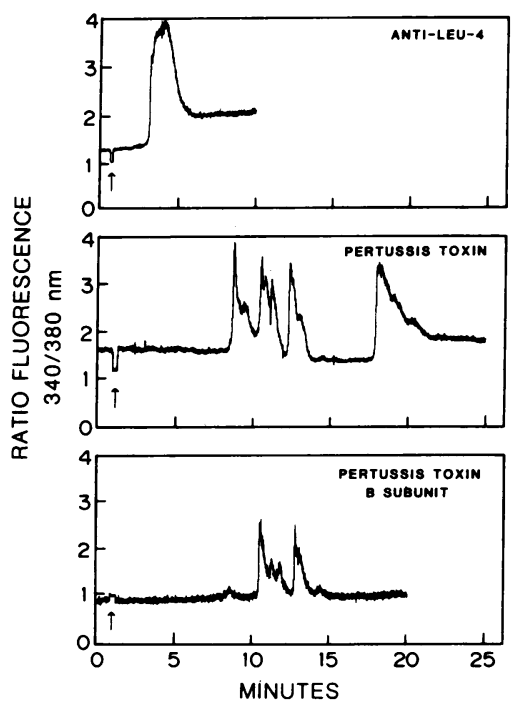

Figure 6. Effects of pertussis toxin on intracellular calcium concentration measured in single cells. Jurkat cells labeled with fura-2 were resuspended in simplified medium and allowed to settle in a viewing chamber. A 12.5- $\mu \mathrm{m}$ pinhole was placed beneath a chosen cell. Stimuli: anti-Leu-4 (top), $1 \mu \mathrm{g} / \mathrm{ml}$ pertussis toxin (middle), or an equimolar amount of $B$ subunit of pertussis toxin (bottom) were added. The ratio of fluorescence excited at 340 $\mathrm{nm}$ versus that excited at $380 \mathrm{~nm}$ measured at $510 \mathrm{~nm}$ was determined. Shown are representative tracings from experiments performed on three separate occasions. 


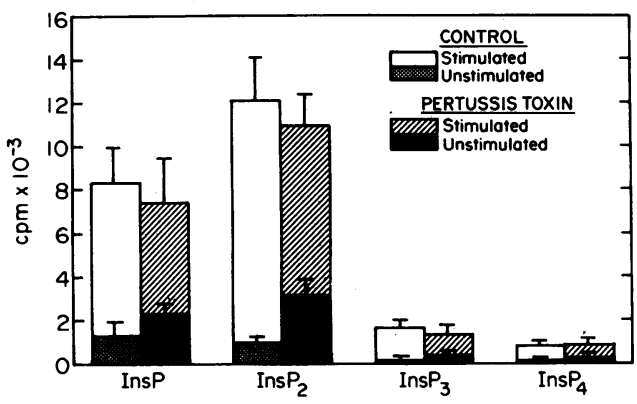

Figure 7. Effect of pertussis toxin on anti-CD3-stimulated inositol phosphates production. Jurkat cells labeled with $\left[{ }^{3} \mathrm{H}\right]$ myo-inositol were pretreated with pertussis toxin or under control conditions, then stimulated or not with the anti-CD3 MAb, anti-Leu-4, and inositol phosphates were analyzed. Data shown represent means and SEM for observations in four separate experiments.

same way that it did in untreated control cells (Fig. 7). This failure of pertussis toxin to inhibit inositol phosphates production occurred at a time when ADP-ribosylation of the inhibitory $G$ protein of adenylate cyclase, $G_{i}$, was near complete (see below, Fig. 11).

Cholera toxin inhibits inositol phosphates formation caused by perturbation of the $T$ lymphocyte antigen receptor/ $C D 3$ complex. Fig. 8 shows the results of experiments in which $\left[{ }^{3} \mathrm{H}\right]$ myo-inositol-labeled Jurkat cells were preincubated with 1 $\mu \mathrm{g} / \mathrm{ml}$ cholera toxin before stimulation of the $\mathrm{T}$ cell receptor/ CD3 complex with the MAb anti-Leu-4. Cholera toxin pretreatment reduced the stimulated increase in total inositol phosphates by $\sim 90 \%$. As cholera toxin is known to affect cellular cAMP levels by its ADP-ribosylation of $\mathrm{G}_{\mathrm{s}}$ and resultant stimulation of the catalytic subunit of adenylate cyclase, we examined the effect of CAMP on inositol phosphates formation in Jurkat cells. Forskolin, a direct activator of the catalytic subunit of adenylate cyclase, was used in concentrations

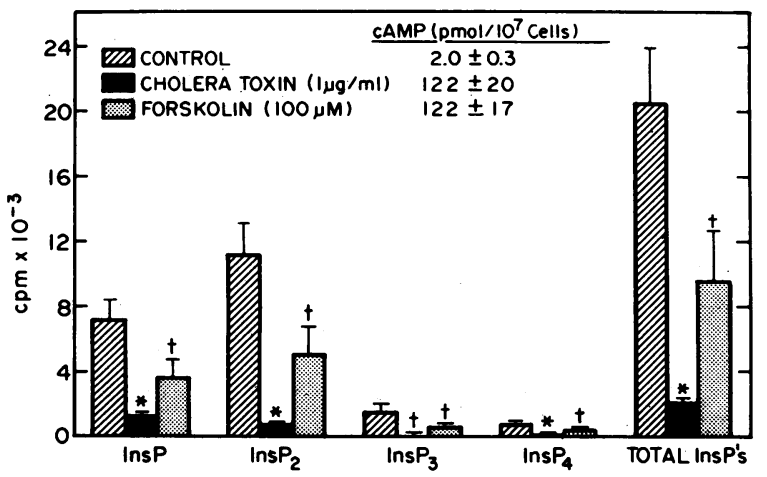

Figure 8. Effect of cholera toxin on inositol phosphates stimulated by perturbation of the $T$ cell antigen receptor-CD 3 complex. Jurkat cells, labeled with $\left[{ }^{3} \mathrm{H}\right]$ myo-inositol, were pretreated under control conditions (striped bars), with $1 \mu \mathrm{g} / \mathrm{ml}$ cholera toxin (black bars), $100 \mu \mathrm{M}$ or forskolin (stippled bars) for $1 \mathrm{~h}$. Cells were then stimulated with anti-Leu-4 MAb for $10 \mathrm{~min}$. Shown are the stimulated increases in various inositol phosphates and total inositol phosphates over the 10-min time period. Data shown represent means and SEM for observations in four separate experiments. Statistical analysis was by one-way ANOVA and Fischer's least significant difference test. *, differs from control and forskolin, $P<0.05$; $\dagger$, differs from control, $P<0.05$.
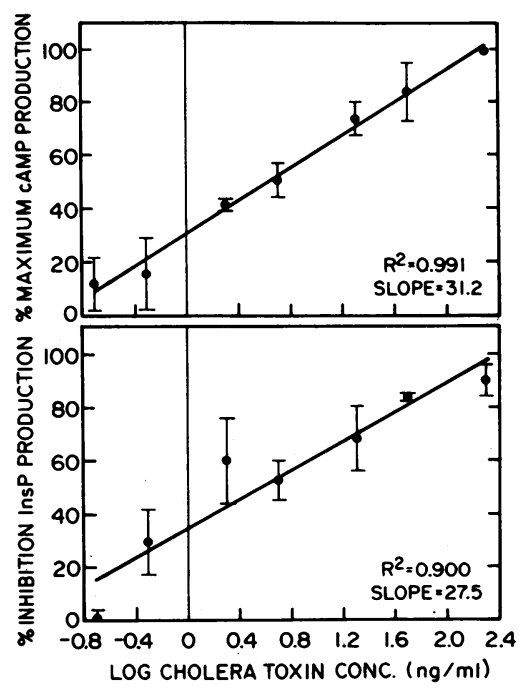

Figure 9. Comparison of cholera toxin-induced inhibition of inositol phosphates production with cAMP production. Jurkat cells, labeled with $\left[{ }^{3} \mathrm{H}\right]$ myoinositol, were treated with cholera toxin at various concentrations for $1 \mathrm{~h}$ and then stimulated with anti-Leu-4 MAb for $10 \mathrm{~min}$. Samples before and after stimulation were analyzed for total inositol phosphates (bottom) and for cAMP contents (top). Shown are means and SEM from three experiments.

equipotent with cholera toxin for cAMP generation. As Fig. 8 demonstrates, equipotent concentrations of forskolin and cholera toxin, produced significantly different effects on stimulated inositol phosphates production. Whereas cholera toxin reduced total inositol phosphates production by $88 \%$, forskolin reduced total inositol phosphate production by only $52 \%$. Next, we examined the cholera toxin dose dependence of cAMP generation versus the dose dependence of suppression of inositol phosphates formation in Jurkat cells, in an attempt to dissociate the two phenomena. As seen in Fig. 9, cholera toxin-induced cAMP production and inhibition of inositol phosphates production demonstrated very similar concentration-response relationships over a 3-log concentration range. In other experiments, addition of $1 \mathrm{mM}$ dibutyryl cAMP during the time of stimulation of Jurkat cells with the anti-CD3 MAb produced a $50 \%$ reduction in inositol phosphates production (data not shown). Therefore, inhibition of inositol phosphates production versus cAMP production was compared for the two agents, cholera toxin and forskolin. Fig. 10 demonstrates that cholera toxin produced much more signifi-

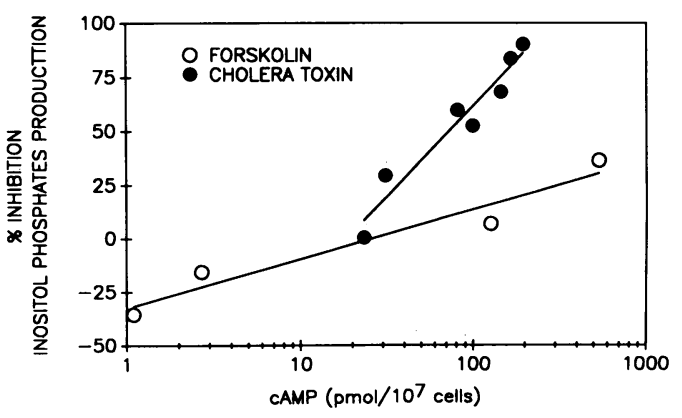

Figure 10. Comparison of inhibition of inositol phosphates production and cAMP production by cholera toxin and forskolin. Jurkat cells, labeled with $\left[{ }^{3} \mathrm{H}\right]$ myo-inositol, were incubated with $2 \mathrm{ng} / \mathrm{ml}$ to $2 \mu \mathrm{g} / \mathrm{ml}$ cholera toxin and $1-500 \mu \mathrm{M}$ forskolin for $1 \mathrm{~h}$, then stimulated with anti-Leu-4 for 10 min. cAMP levels and $\left[{ }^{3} \mathrm{H}\right]$ myo-inositol in total inositol phosphates in pre- and poststimulation cell samples were determined. Data represent the average of the pre- and poststimulation values. 
cant inhibition of inositol phosphates production than did forskolin for the amount of cAMP generated. These data suggest that cholera toxin may inhibit inositol phosphates production through a mechanism other than production of cAMP.

Biffen and Martin (44) have demonstrated that cholera toxin can inhibit incorporation of inositol into phosphoinositide pools in rat hepatocyte membranes. This inhibition was independent of cholera toxin effects on CAMP and potentially mediated through inhibition of phosphatidylinositol kinase. Since inhibition of incorporation of label into the substrates of phospholipase $\mathrm{C}$ could account for the inhibition of inositol phosphates production seen in Figs. 8, 9, and 10, we examined the effect of cholera toxin on labeling of phosphoinositides in Jurkat cells. Fig. 11 demonstrates that, whereas 1 $\mu \mathrm{g} / \mathrm{ml}$ cholera toxin caused a 100 -fold increase in cAMP in these cells, its effects on phosphoinositide labeling were minimal with no apparent change in the $\left[{ }^{3} \mathrm{H}\right]$ inositol incorporation into $\mathrm{PI}$ and $\mathrm{PIP}_{2}$ and a marginally significant decrease in incorporation into PIP. Whereas these cells were labeled in such a way that isotopic equilibrium had not been reached, and therefore, measured $\left[{ }^{3} \mathrm{H}\right]$ myo-inositol incorporation could not be considered necessarily proportional to mass, such small changes in substrate labeling would appear unlikely to account for the $\sim 90 \%$ inhibition of inositol phosphates production noted in Fig. 8. However, since PI kinase activity was not measured directly, it remains possible that cholera toxin could act via inhibition of incorporation of label into the phosphoinositide pools that would become apparent only when phospholipase $\mathrm{C}$ was activated and consuming substrate.

Toxin effects on $T$ cell antigen receptor/CD3 complex expression. One possible explanation of the cholera toxin pretreatment inhibition of stimulated inositol phosphates formation would be reduction in $T$ cell antigen receptor/CD3 complex number. Imboden and colleagues (35) have reported that treatment of Jurkat cells with $0.1 \mu \mathrm{g} / \mathrm{ml}$ cholera toxin for $3 \mathrm{~h}$ reduced antigen receptor/CD3 complex numbers on the cell surface, but that this reduced CD3 expression did not account for the observed effects on calcium mobilization. Similarly, decreased CD3 expression does not appear to be a sufficient explanation of cholera toxin effects during the 1-h preincubations used in the experiments reported here. Table I shows that pretreatment with $1 \mu \mathrm{g} / \mathrm{ml}$ cholera toxin for $1 \mathrm{~h}$ led to insignificant changes in CD3 antigen expression. Similarly, insignificant changes in fluorescence were noted after incubation with either pertussis toxin or forskolin. No changes were noted in

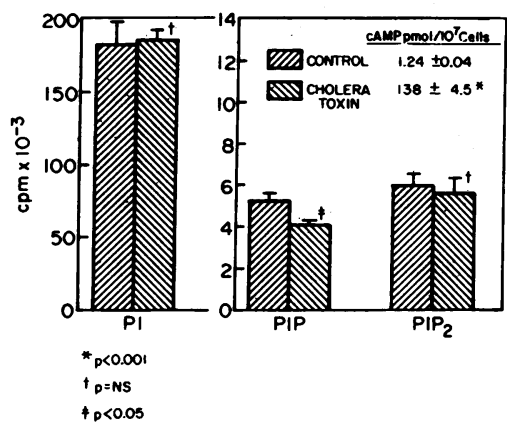

Figure 11. Effect of cholera toxin on phosphoinositide labeling. Jurkat cells, labeled with $\left[{ }^{3} \mathrm{H}\right]$ myo-inositol, were incubated with 1 $\mu \mathrm{g} / \mathrm{ml}$ cholera toxin for $1 \mathrm{~h}$. Cells were lysed in $10 \%$ TCA. Supernatants were analyzed for cAMP content, whereas precipitated material was analyzed for incor-

poration of label into phosphoinositides. Data presented represent the means and SEM for triplicate determinations. Statistical analysis was by $t$ test. $*, P<0.001 ; \dagger, P=\mathrm{NS} ; \ddagger, P<0.05$.
Table I. Effect of Toxins on CD3 Expression on Jurkat Cells

\begin{tabular}{llll}
\hline & \multicolumn{3}{c}{ Specific fluorescence* } \\
\cline { 2 - 4 } \multicolumn{1}{c}{ Treatment } & CD3 & CD2 & $\begin{array}{c}\text { Transferrin } \\
\text { receptor }\end{array}$ \\
\hline Control & $99 \pm 8$ & $325 \pm 12$ & $53 \pm 5$ \\
Pertussis toxin & $92 \pm 8$ & $325 \pm 10$ & $55 \pm 6$ \\
Cholera toxin & $80 \pm 8$ & $329 \pm 9$ & $38 \pm 5$ \\
Forskolin & $92 \pm 8$ & $335 \pm 9$ & $51 \pm 5$ \\
\hline
\end{tabular}

* Specific fluorescence is expressed as mean channel linear fluorescence (MCLF) of a given antigen minus MCLF of CD8 (negative control). Data shown represent the mean \pm SEM for three separate ex periments. No significant changes in specific fluorescence were seen within an antigen group. Statistical analysis was by one-way ANOVA and Fisher's least significant difference test.

CD2 expression under the conditions used. Retained CD2 expression is significant because some authors have suggested that $\mathrm{T}$ cell receptor/CD3 complex-mediated activation may be tied to the CD2 machinery (45).

Substrates for toxin-catalyzed ADP-ribosylation in Jurkat cells. Jurkat cells were examined for targets of the ADPribosyltransferase activity of the toxins. Membranes were prepared from Jurkat cells that had been preincubated for $1 \mathrm{~h}$ without toxin or with cholera toxin or pertussis toxin. Membrane preparations were then incubated with ${ }^{32}$ P-NAD without or with the relevant, activated toxin. Fig. 12 demonstrates that in Jurkat membranes, pertussis toxin specifically ADP-ribosylated a 41-kD protein, whereas cholera toxin specifically ADP-ribosylated a 45-kD substrate. In general, the major labeled proteins were indistinguishable from $G_{i}$ and $G_{s}$, by the techniques of one dimensional SDS-PAGE. Although it is possible that other $G$ proteins might not be resolved from $G_{s}$ and $\mathrm{G}_{i}$ by this technique, the results fail to demonstrate novel Gproteins which might couple the $\mathrm{T}$ cell antigen receptor-CD3 complex to phospholipase C.

\section{Discussion}

The data presented here demonstrate that bacterial toxins affect two important aspects of early $T$ lymphocyte activation, inositol phosphates production, and intracellular calcium increase. Our observations provide a molecular basis for the clinical and in vitro observations of lymphocyte proliferation in response to pertussis toxin. Pertussis toxin through a lectinlike action of its binding subunit increases inositol phosphate production and leads to early increases in $\left[\mathrm{Ca}^{2+}\right]_{i}$. Our obser-

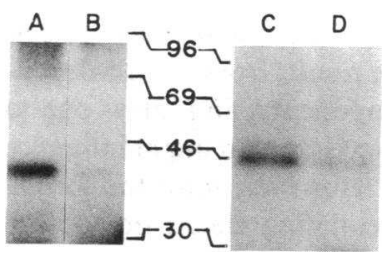

Figure 12. Substrates for ADP-ribosyltransferase activities of pertussis and cholera toxin. Membrane preparations from untreated (lanes $A$ and $C$ ), pertussis toxinpretreated (lane $B$ ), or cholera toxin-pretreated (lane $D$ ) Jurkat cells were incubated with activated pertussis toxin (lanes $A$ and $B$ ) or activated cholera toxin (lanes $C$ and $D$ ) in the presence of ${ }^{32} \mathrm{P}-\mathrm{NAD}$. Labeled membrane proteins were examined by one-dimensional SDS-PAGE and autoradiography. 
vations provide an explanation for the findings of Tamura et al. (46) that the pertussis toxin B subunit alone can produce lymphocyte proliferation as measured by $\left[{ }^{3} \mathrm{H}\right]$ thymidine incorporation.

Our results differ from those obtained by Ledbetter and colleagues, who have reported that pertussis toxin pretreatment abolishes the anti-CD3-stimulated increase in $\left[\mathrm{Ca}^{2+}\right]_{i}$ $(47,48)$. However, those investigators studied $T$ lymphocytes from peripheral blood that had been pretreated with a high concentration of pertussis toxin $(10 \mu \mathrm{g} / \mathrm{ml})$, or 10 times the concentration used here. Furthermore, the inhibition of stimulated increases in $\left[\mathrm{Ca}^{2+}\right]_{i}$ was not shown to be dependent upon the A subunit of pertussis toxin. Based on our data, we would suggest that anti-CD3 MAb failed to stimulate an increase in $\left[\mathrm{Ca}^{2+}\right]_{i}$ in those studies because the cells had been maximally stimulated by the high concentration of pertussis toxin $B$ chain.

Pertussis toxin-induced changes may differ from those induced by well-characterized mitogens. The pulsatile pattern of intracellular calcium changes detected in single-cell experiments with fura-2, differ from the larger, more consistently sustained changes that occur in response to anti-CD3 MAb (see again Fig. 6) or potent plant mitogens such as Con A (reference 49, and unpublished observations). Similar oscillations in $\left[\mathrm{Ca}^{2+}\right]_{i}$ have been reported in rat hepatocytes after stimulation with alpha-adrenergic agonists or vasopressin (50). These observations raise questions regarding the nature of the calcium stimulus required for commitment of the cell to new mRNA formation and to proliferation. Frequency-modulated signaling may offer advantages over amplitude-modulated signaling for control of activation processes (51).

Pertussis toxin fails to inhibit anti-CD3-induced inositol phosphate formation in this $\mathrm{T}$ lymphocyte system. Therefore, if $\mathrm{G}$ protein coupling of the $\mathrm{T}$ cell receptor-CD3 complex to phospholipase $C$ exists, the relevant $G$ protein may be more closely related to the $G$ proteins responsible for signal transduction in rat hepatocytes (52) and cardiac myocytes (53) than to the pertussis toxin-sensitive $G$ protein involved in chemotactic peptide activation of neutrophils (18-20).

Our observations regarding cholera toxin effects on $\mathrm{T}$ lymphocyte activation serve to continue a protracted debate (54) over the role of cAMP in inhibition of T cell proliferation. The results detailed here, stand between the work of Imboden and colleagues (35), which suggests that cholera toxin inhibition of inositol phosphate production and increases in $\left[\mathrm{Ca}^{2+}\right]_{i}$ are independent of effects of cholera toxin on adenylate cyclase and that of Patel et al. (55), which suggests that complete inhibition of inositol phosphate production can be accomplished with cAMP analogues. Our data using forskolin to elevate cAMP to levels equal to those attained by cholera toxin treatment of cells demonstrate a significant difference in inositol phosphate production between forskolin-treated and cholera toxintreated Jurkat cells. The results could be interpreted as evidence that cholera toxin inhibition results from cAMP-dependent and cAMP-independent components, and allow one to suggest that a cholera toxin sensitive $G$ protein might influence phospholipase $\mathrm{C}$ activity directly. However, until the formal possibility that forskolin has potentiating effects on inositol phosphates production can be eliminated, some caution should be exercised with regard to this conclusion. Cholera toxin inhibition of stimulated inositol phosphates formation did not appear to result from reduction in baseline polyphos- phoinositide labeling, but cholera toxin inhibition of phosphoinositide kinase under stimulated conditions could not be ruled out.

Therefore, in the $\mathrm{T}$ lymphocyte, data unequivocally supporting $G$ protein involvement in the signal transduction after perturbation of the antigen receptor-CD3 complex remain elusive. Toxins exert potent effects independent of their ADPribosyltransferase capacities. For example, the binding subunit of pertussis toxin can act as a mitogen in the $T$ lymphocyte system. Furthermore, simultaneous effects of toxins on multiple guanine nucleotide-binding regulatory proteins, both known and potentially unrecognized, make narrow interpretation of results hazardous. The results presented here underline the complexity of toxin effects on cellular systems, demonstrate the necessity of toxin subunit controls for proper experimental interpretation, and suggest that more direct biochemical investigation will be required to explain the role of $\mathrm{G}$ proteins in $\mathrm{T}$ lymphocyte activation.

\section{Addendum}

Since submission of this paper, similar results of increased inositol phosphate production and $\left[\mathrm{Ca}^{2+}\right]_{i}$ after pertussis toxin stimulation of Jurkat cells have been reported by Rosoff et al. (56). Also, Banga et al. (57) have suggested that the B subunit of pertussis toxin may activate platelets independently of the toxin's ADP-ribosylating activity.

\section{Acknowledgments}

This work was supported in part by research grants GM-38610, CA-33589, and HL-36020, and Biomedical Research Support Grant Program S07-RR05424, Division of Research Resources, National Institutes of Health, and by the Veterans Administration. Portions of this study were carried out in the Stahlman Cardiovascular Research Program.

\section{References}

1. Ueda, K., and O. Hayaishi. 1985. ADP-ribosylation. Annu. Rev. Biochem. 54:73-100.

2. Gilman, A. G. 1987. G proteins: transducers of receptor-generated signals. Annu. Rev. Biochem. 56:615-649.

3. Gilman, A. G. 1984. G proteins and dual control of adenylate cyclase. Cell. 36:577-579.

4. Northrup, J. K. 1985. Overview of the guanine nucleotide regulatory protein systems, $N_{s}$ and $N_{i}$, which regulate adenylate cyclase activity in plasma membranes. In Molecular Mechanisms of Transmembrane Signalling. P. Cohen and M. D. Houslay, editors. Elsevier Science Publishers, Amsterdam. 91-116.

5. Birnbaumer, L., J. Codina, R. Mattera, R. A. Cerione, J. D. Hildebrandt, T. Sunyer, F. J. Rojas, M. G. Caron, R. J. Lefkowitz, and $R$. Iyengar. 1985. Structural basis of adenylate cyclase stimulation and inhibition by distinct guanine nucleotide regulatory proteins. In Molecular Mechanisms of Transmembrane Signalling. P. Cohen and M. D. Houslay, editors. Elsevier Science Publishers, Amsterdam. 131-182.

6. Ribiero-Neto, F. A. P., R. Mattera, J. D. Hildebrandt, J. Codina, J. B. Field, L. Birnbaumer, and R. D. Sekura. 1985. ADP-ribosylation of membrane components by pertussis and cholera toxin. Methods Enzymol. 109:566-572.

7. Berridge, M. J., and R. F. Irvine. 1984. Inositol trisphosphate, a novel second messenger in cellular signal transduction. Nature (Lond.). 312:315-321.

8. Nishizuka, Y. 1986. Studies and perspectives of protein kinase C. Science (Wash. DC). 233:305-312. 
9. Berridge, M. J. 1983. Rapid accumulation of inositol trisphosphate reveals that agonists hydrolyse polyphosphoinositides instead of phosphatidylinositol. Biochem. J. 212:849-858.

10. Cockcroft, S., and B. D. Gomperts. 1985. Role of guanine nucleotide binding protein in the activation of polyphosphoinositide phosphodiesterase. Nature (Lond.). 314:534-536.

11. Smith, C. D., C. C. Cox, and R. Snyderman. 1986. Receptorcoupled activation of phosphoinositide-specific phospholipase $\mathrm{C}$ by an N protein. Science (Wash. DC). 232:97-100.

12. Smith, C. D., B. C. Lane, I. Kusuka, M. W. Verghese, and R. Snyderman. 1985. Chemoattractant receptor-induced hydrolysis of phosphatidylinositol 4,5-bisphosphate in human polymorphonuclear leukocyte membranes. J. Biol. Chem. 260:5875-5878.

13. Backlund, P. S., B. D. Meade, C. R. Manclark, G. L. Cantoni, and R. R. Aksamit. 1985. Pertussis toxin inhibition of chemotaxis and the ADP-ribosylation of a membrane protein in a human-mouse hybrid cell line. Proc. Natl. Acad. Sci. USA. 82:2637-2641.

14. Okajima, F., T. Katada, and M. Ui. 1985. Coupling of the guanine nucleotide regulatory protein to chemotactic peptide receptors in neutrophil membranes and its uncoupling by islet-activating protein, pertussis toxin. J. Biol. Chem. 260:6761-6768.

15. Goldman, D. W., F. H. Chang, L. A. Gifford, E. J. Goetzl, and H. R. Bourne. 1985. Pertussis toxin inhibition of chemotactic factorinduced calcium mobilization and function in human polymorphonuclear leukocytes. J. Exp. Med. 162:145-156.

16. Krause, K. H., W. Schlegel, C. B. Wollheim, T. Andersson, F. A. Waldvogel, and P. D. Lew. 1985. Chemotactic peptide activation of human neutrophils and HL-60 cells. Pertussis toxin reveals correlation between inositol trisphosphate generation, calcium ion transients, and cellular activation. J. Clin. Invest. 76:1348-1354.

17. Lad, P. M., C. V. Olson, I. S. Grewal, and S. J. Scott. 1985. A pertussis toxin-sensitive GTP-binding protein in the human neutrophil regulates multiple receptors, calcium mobilization, and lectin-induced capping. Proc. Natl. Acad. Sci. USA. 82:8643-8647.

18. Verghese, M., R. J. Uhing, and R. Snyderman. 1986. A pertussis/choleratoxin-sensitive $\mathrm{N}$ protein may mediate chemoattractant receptor signal transduction. Biochem. Biophys. Res. Commun. 138:887-894.

19. Smith, C. D., R. J. Uhing, and R. Snyderman. 1987. Nucleotide regulatory protein-mediated activation of phospholipase $C$ in human polymophonuclear leukocytes is disrupted by phorbol esters. J. Biol. Chem. 262:6121-6127.

20. Gieschik, P., D. Sidiropoulos, A. Spiegel, and K. H. Jakobs. 1987. Purification and immunochemical characterization of the major pertussis toxin-sensitive guanine nucleotide-binding protein of bovine neutrophil membranes. Eur. J. Biochem. 165:185-194.

21. Weiss, A., J. Imboden, K. Hardy, B. Manger, C. Terhorst, and J. Stobo. 1986. The role of the T3/antigen receptor complex in T-cell activation. Annu. Rev. Immunol. 4:593-619.

22. Meuer, S. C., J. C. Hodgdon, R. E. Hussey, J. P. Protentis, S. F. Schlossman, and E. L. Reinherz. 1983. Antigen-like effects of monoclonal antibodies directed at receptor on human T cell clones. J. Exp. Med. 158:988-993.

23. Imboden, J. B., and J. D. Stobo. 1985. Transmembrane signalling by the $T$ cell antigen receptor. Perturbation of the T3-antigen receptor complex generates inositol phosphates and releases calcium ions from intracellular stores. J. Exp. Med. 161:446-456.

24. Stewart, S. J., V. Prpic, F. S. Powers, S. B. Bocckino, R. E. Isaacks, and J. H. Exton. 1986. Perturbation of the human T-cell antigen receptor- $\mathrm{T} 3$ complex leads to the production of inositol tetrakisphosphate: evidence for conversion from inositol trisphosphate. Proc. Natl. Acad. Sci. USA. 83:6098-6102.

25. Weiss, A., J. Imboden, D. Shoback, J. Stobo. 1984. Role of T3 surface molecules in human T-cell activation: T3-dependent activation results in an increase in cytoplasmic free calcium. Proc. Natl. Acad. Sci. USA. 81:4169-4173.

26. Imboden, J. B., A. Weiss, and J. D. Stobo. 1985. The antigen receptor on a human $\mathrm{T}$ cell line initiates activation by increasing cytoplasmic free calcium. J. Immunol. 134:663-665.

27. Wiskocil, R., A. Weiss, J. Imboden, R. Kamin-Lewis, and J. Stobo. 1985. Activation of a human $T$ cell line: a two stimulus requirement in the pretranslational events involved in the coordinate expression of interleukin 2 and gamma-interferon genes. J. Immunol. 134:1599-1603.

28. Hara, T., and S. Man Fu. 1985. Human T cell activation. I. Monocyte-independent activation and proliferation induced by antiT3 monoclonal antibodies in the presence of tumor promoter 12-otetradecanoyl phorbol-13-acetate. J. Exp. Med. 161:641-656.

29. van Wauwe, J. P., J. R. deMey, and J. G. Goossens. 1980. OKT3: a monoclonal anti-human $T$ lymphocyte antibody with potent mitogenic properties. J. Immunol.-124:2708-2713.

30. Moretta, A., G. Pantaleo, M. Lopez-Botet, M. C. Mingari, and L. Moretta. 1985. Anticlonotypic monoclonal antibodies induce proliferation of clonotype-positive $\mathrm{T}$ cells in peripheral blood human $\mathrm{T}$ lymphocytes. J. Exp. Med. 162:1393-1398.

31. Wilkins, J., and P. F. Wehrle. 1985. Bordetella species (including whooping cough). In Principles and Practice of Infectious Disease. G. L. Mandell, R. G. Douglas, and J. E. Bennett, editors. John Wiley \& Sons, New York. 1301-1305.

32. Kong, A. S., and S. I. Morse. 1977. The in vitro effects of Bordetella pertussis lymphocytosis-promoting factor on murine lymphocytes. I. Proliferative response. J. Exp. Med. 145:151-162.

33. Kong, A. S., and S. I. Morse. 1977. The in vitro effects of Bordetella pertussis lymphocytosis-promoting factor on murine lymphocytes. II. Nature of the responding cells. J. Exp. Med. 145:163-174.

34. Vistica, B. P., C. G. McAllister, R. D. Sekura, J. N. Ihle, and I. Gery. 1986. Dual effects of pertussis toxin on lymphoid cells in culture. Cell. Immunol. 101:232-241.

35. Imboden, J. B., D. M. Shoback, G. Pattison, and J. D. Stobo. 1986. Cholera toxin inhibits the T-cell antigen receptor-mediated increases in inositol trisphosphate and cytoplasmic free calcium. Proc. Natl. Acad. Sci. USA. 83:5673-5677.

36. Gillis, S., and J. Watson. 1980. Biochemical and biological characterization of lymphocyte regulatory molecules. V. Identification of an interleukin-2 producing human leukemia T cell line. J. Exp. Med. 152:1709-1719.

37. Kan, E. A. R., C. Y. Wang, L. C. Wang, and R. L. Evans. 1983. Noncovalently bonded subunits of 22 and $28 \mathrm{kD}$ are rapidly internalized by $\mathrm{T}$ cells reacted with anti-Leu-4 antibody. J. Immunol. 131:536-539.

38. Bergman, Y., S. J. Stewart, S. Levy, and R. Levy. Biosynthesis, glycosylation, and in vitro translation of the human $T$ cell antigen Leu-4. J. Immunol. 131:1876-1881.

39. Burns, D. L., J. G. Kenimer, and C. R. Manclark. 1987. Role of the A subunit of pertussis toxin in alteration of Chinese hamster ovary cell morphology. Infect. Immun. 55:24-28.

40. Grynkewicz, G., M. Poenie, and R. Y. Tsien. 1985. A new generation of $\mathrm{Ca}^{2+}$ indicators with greatly improved fluorescence properties. J. Biol. Chem. 260:3440-3450.

41. Tsien, R. Y., T. Pozzan, and T. J. Rink. 1982. Calcium homeostasis in intact lymphocytes: cytoplasmic free calcium monitored with a new, intracellularly trapped fluorescent indicator. J. Cell Biol. 94:325-334.

42. Brooker, G., J. F. Harper, W. L. Terasaki, and R. D. Moylan. 1979. Radioimmunoassay of cyclic AMP and cyclic GMP. Adv. Cyclic Nucleotide Res. 10:1-33.

43. Laemmli, U. K. 1970. Cleavage of structural proteins during the assembly of the head of bacteriophage T4. Nature (Lond.). 227:680-685.

44. Biffen, M., and B. R. Martin. 1987. Polyphosphoinositide labeling in rat liver plasma membranes is reduced by preincubation with cholera toxin. J. Biol. Chem. 262:7744-7750.

45. Alcover, A., M. J. Weiss, J. F. Daley, and E. L. Reinherz. 1986. The T11 glycoprotein is functionally linked to a calcium channel in 
precursor and mature T-lineage cells. Proc. Natl. Acad. Sci. USA. 83:2614-2618.

46. Tamura, M., K. Nogimori, M. Yajima, K. Ase, and M. Ui. 1983. A role of the B-oligomer moiety of islet-activating protein, pertussis toxin, in development of the biological effects on intact cells. $J$. Biol. Chem. 258:6756-6761.

47. Ledbetter, J. A., L. E. Gentry, C. H. June, P. S. Rabinovitch, and A. F. Purchio. 1987. Stimulation of T cells through the CD3/T-cell receptor complex: role of cytoplasmic calcium, protein kinase $C$ translocation, and phosphorylation of pp60 $60^{\mathrm{ssc}}$ in the activation pathway. Mol. Cell. Biol. 7:650-656.

48. Ledbetter, J. A., C. H. June, L. S. Grosmaire, and P. S. Rabinovitch. 1987. Crosslinking of surface antigens causes mobilization of intracellular ionized calcium in T lymphocytes. Proc. Natl. Acad. Sci. USA. 84:1384-1388.

49. Weiss, A., R. Shields, M. Newton, B. Manger, and J. Imboden. 1987. Ligand-receptor interactions required for commitment to the activation of the interleukin 2 gene. J. Immunol. 138:2169-2176.

50. Woods, N. M., K. S. R. Cuthbertson, and P. H. Cobbold. 1987. Agonist-induced oscillations in cytoplasmic free calcium concentration in single rat hepatocytes. Cell Calcium. 8:79-100.
51. Campbell, A. K. 1983. Intracellular Calcium. Its Universal Role as Regulator. John Wiley \& Sons, New York.

52. Uhing, R. J., V. Prpic, H. Jiang, and J. H. Exton. 1986. Hormone-stimulated polyphosphoinositide breakdown in rat liver plasma membranes. Roles of guanine nucleotides and calcium. J. Biol. Chem. 261:2140-2146.

53. Masters, S. B., M. W. Martin, T. K. Harden, and J. H. Brown. 1985. Biochem. J. 227:933-937.

54. Parker, C. W. 1979. Role of cyclic nucleotides in regulating lymphocytes. Ann. NY Acad. Sci. 332:255-261.

55. Patel, M. D., L. E. Samelson, and R. D. Klausner. 1987. Multiple kinases and signal transduction: phosphorylation of the $T$ cell antigen receptor complex. J. Biol. Chem. 262:5831-5838.

56. Rosoff, P. M., R. Walker, and L. Winberry. 1987. Pertussis toxin triggers rapid second messenger production in human $T$ lymphocytes. J. Immunol. 139:2419-2423.

57. Banga, H. J., R. K. Walker, L. K. Winberry, and S. E. Rittenhouse. 1987. Pertussis toxin can activate human platelets. J. Biol. Chem. 262:14871-14874. 